\title{
WAKTU TRANSIT, NILAI ORGANOLEPTIK, DAN NILAI KEASAMAN (PH): HASIL TANGKAPAN PURSE SEINE
}

\author{
Rahmatang, M. Prihajatno, Irwan \\ Politeknik Kelautan dan Perikanan Bone, Sulawesi Selatan \\ Jl. Sungai Musi KM.9, Waetuo-Watampone, Sulawesi Selatan \\ Email : prihajatno.m16@gmail.com
}

\begin{abstract}
ABSTRAK
Penelitian ini bertujuan untuk mengetahui pengaruh antara fasilitas penanganan, cara penanganan, dan waktu transit dengan kualitas ikan pada alat tangkap purse seine. pengukuran pH dan nilai organoleptik lima jenis ikan yang dominan tertangkap di atas kapal, di Tempat Pelelangan Ikan (TPI) sebelum dilelang, dan di TPI sesaat setelah dilelang. Pengamatan juga dilakukan terhadap kondisi fasilitas dan cara penanganan di atas kapal dan di TPI dan durasi waktu sejak ikan ditangkap sampai selesai dilelang. Hubungan fasilitas penanganan, cara penanganan, dan waktu transit dengan kualitas ikan ditentukan menggunakan analisis uji t, regresi linear sederhana, dan regresi linear berganda. Lima Jenis ikan yang dominan tertangkap adalah cakalang (Katsuwonus pelamis), kembung lelaki (Rastrelliger kanagurta), kembung perempuan (Rastrelliger brachysoma), tembang (Sardinella), dan layang (Decapterus ruselli). Berdasarkan hasil analisis fasilitas penanganan di atas kapal dan di TPI, cara penanganan di TPI, dan waktu transit tidak berbeda $(\mathrm{p}>0,05)$. Hubungan nilai $\mathrm{pH}$ dengan organoleptik ikan diprediksi berdasarkan persamaan $\mathrm{Y}=0,3978 \mathrm{x}+2,7662 ; \mathrm{R} 2=0,9977$, jika nilai organoleptik $(\mathrm{X})=0$ maka nilai $\mathrm{pH}(\mathrm{Y})=2,7662$. Fasilitas penanganan di atas kapal $(\mathrm{X} 1)$, cara penanganan di atas kapal (X3), dan waktu transit (X5) menentukan kualitas (organoleptik) sebesar 17,1\% dengan persamaan regresi $\mathrm{Y}=7,293$ $0,1461 \mathrm{X} 1+0,0193 \mathrm{X} 3+0,1265 \mathrm{X} 5 ; \mathrm{R} 2=0,171$, sedangkan kualitas $(\mathrm{pH})$ ditentukan hanya sebesar 4,4\% oleh fasilitas penanganan di atas kapal (X1), cara penanganan di atas kapal (X3), dan waktu transit (X5) dengan persamaan $\mathrm{Y}=5,697-0,0761 \mathrm{X} 1+0,1233 \mathrm{X} 3+0,0125 \mathrm{X} 5 ; \mathrm{R} 2=0,044$, sedangkan 95,6\% dipengaruhi variabel lain..
\end{abstract}

Kata kunci :cara penanganan, waktu transit, kualitas ikan, Barru, purse seine

\begin{abstract}
This study aims to determine the effect of handling facilities, handling methods, and transit time with the quality of fish in the purse seine fishing gear. measurement of $\mathrm{pH}$ and organoleptic value of five dominant fish species caught on board, at the Fish Auction Place (TPI) before being auctioned, and at the TPI shortly after being auctioned. Observations were also made on the condition of the facility and how to handle it on board and at the TPI and the duration of time since the fish was caught until it was finished auctioned. The relationship between handling facilities, handling methods and transit times with fish quality was determined using test analysis, simple linear regression, and multiple linear regression. Five dominant fish species were Katsuwonus pelamis, Rastrelliger kanagurta, Rastrelliger brachysoma, Sardinella, and Decapterus ruselli. Based on the results of the analysis of the aboard handling facilities and in the TPI, how to handle the TPI, and the transit time is not different $(\mathrm{p}>0.05)$. The relationship of $\mathrm{pH}$ value with organoleptic fish was predicted based on the equation $\mathrm{Y}=$ $0.3978 x+2.7662 ; \mathrm{R} 2=0.9977$, if the organoleptic value $(\mathrm{X})=0$ then the $\mathrm{pH}$ value $(\mathrm{Y})=2.7662$. Aboard handling facilities (X1), handling methods on board (X3), and transit time (X5) determine the quality (organoleptic) of $17.1 \%$ with the regression equation $\mathrm{Y}=7.293-0.1461 \mathrm{X} 1+0.0193 \mathrm{X} 3+0.1265 \mathrm{X} 5$, R2 = 0.171 , while the quality $(\mathrm{pH})$ was determined only at $4.4 \%$ by the above ship handling facility (X1), the method of handling on board (X3), and transit time (X5) with the equation $\mathrm{Y}=5,697-0.0761 \mathrm{X} 1+0.1233 \mathrm{X} 3+$ $0.0125 \times 5 ; \mathrm{R} 2=0.044$, while $95.6 \%$ is influenced by other variables.
\end{abstract}

Keywords: handling method, transit time, fish quality, Barru, purse seine 


\section{PENDAHULUAN}

Hasil perikanan merupakan komoditas pangan yang paling mudah mengalami proses kemunduran mutu yang disebabkan oleh kandungan air yang tinggi dan nutrisi yang lengkap sehingga tubuh ikan merupakan media yang sangat cocok untuk perkembangbiakan bakteri pembusuk. Ikan yang baru saja mati berada dalam tingkat kesegaran yang maksimum, artinya kesegaran ikan tidak bisa ditingkatkan hanya dapat dipertahankan melalui penerapan prinsip pananganan yang baik dan benar.

Secara umum setiap jenis ikan memiliki pola dan kecepatan penurunanan mutu yang berbeda-beda. Berbagai faktor yang mempengaruhinya baik yang bersifat internal maupun eksternal. Faktor internal antara lain jenis ikan, kondisi fisik, dan proses kematian ikan. Ikan yang mati akibat menggelepar atau berdesak-desakan lebih cepat membusuk daripada ikan yang mati seketika (Adawyah, 2007). Faktor eksternal seperti cara penangkapan, fasilitas, proses penanganan dan waktu transit. Kecepatan penurunan mutu ikan yang mengalami luka atau memar lebih tinggi dibandingkan dengan ikan dengan kondisi fisik yang utuh (Hadiwiyoto, 1993).

Fasilitas kapal penangkap, cara penangkapan, dan waktu transit ikan dari kapal hingga selesai dilelang di TPI merupakan hal yang berpengaruh langsung terhadap kualitas ikan yang akan dipasarkan. Untuk mempertahankan tingkat kesegaran ikan yang baru saja mati dilakukan penerapan suhu rendah sesegera mungkin seperti pendinginan menggunakan es dengan cara yang baik dan benar. Cara ini harus didukung oleh penggunaan wadah yang berinsulasi yang dapat mempertahankan suhu pendinginan sehingga proses penurunan mutu baik yang berlangsung secara enzimatis, biokimiawi dan mikrobiologis dapat dihambat (Hadiwiyoto, 1993).

Purse seinemerupakan alat tangkap yang menyebabkan ikan mati akibat menggelepar dan berdesak-desakan sehingga terjadi akumulasi asam laktat dari pemecahan glikogen dalam jaringan. Hal ini berpotensi mempercepat laju penurunan mutu jika ikan tidak segera ditangani dengan baik dan benar. Penelitian yang bertujuan untuk mengetahui hubungan berbagai faktor seperti fasilitas penanganan, cara penanganan, dan waktu transit dengan kualitas ikan sejak ikan mati diatas kapal hingga selesai dilelang di TPI dipandang penting untuk dilakukan. Alat tangkap yang digunakan dalam objek penelitian adalah purse seine dengan pengoperasian di perairan Kabupaten Barru. Parameter kualitas ikan diwakili oleh $\mathrm{pH}$ dan organoleptik. Hal ini penting karena kualitas ikan yang akan dipasarkan atau diolah oleh industri perikanan secara umum ditentukan oleh kualitas ikan yang ada di TPI. Selain itu FAO telah memprediksi bahwa terjadi 
kehilangan pascapanen sekitar $25 \%$ dari total hasil tangkapan akibat kelalaian cara penanganan.

\section{METODE PENELITIAN}

Penelitian dilakukan dilakukan di perairan Kabupaten Barru - Sulawesi Selatan, pada Bulan November sampai dengan Desember 2012. Operasi penangkapan dengan menggunakan kapal ikan dengan alat tangkap purse seine. Gambar 1 berikut memperlihatkan daerah operasi penangkapan ikan yang menjadi obyek penelitian.

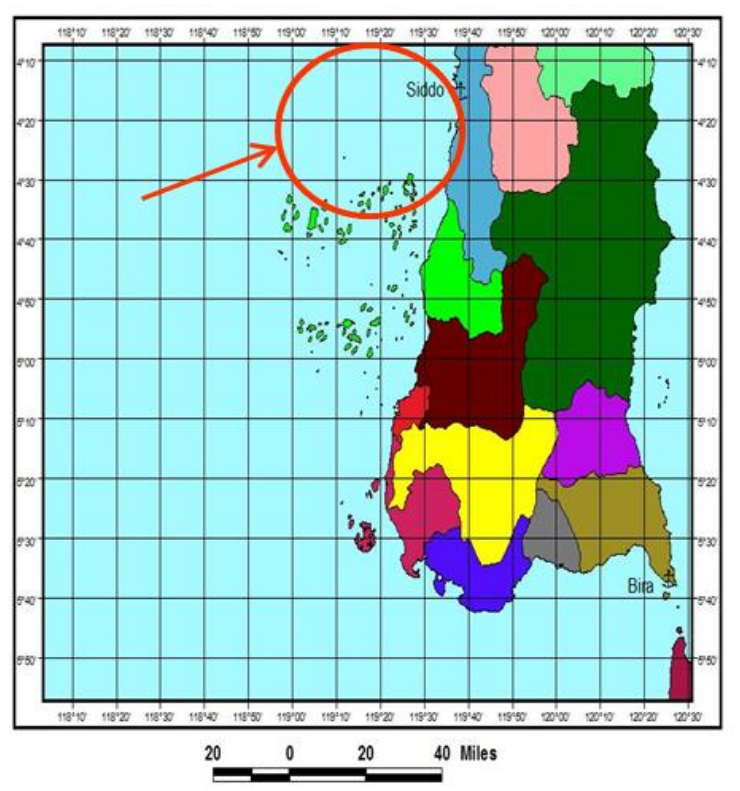

Gambar 1. Daerah operasi penangkapan ikan obyek penelitian.

Penelitian dilakukan dengan metode survei melalui observasi secara langsung dengan mengikuti operasi penangakapan ikan pada purse seine di perairan Kabupaten Barru 5 trip. Survei dilakukan untuk mengumpulkan data primer sifat organoleptik dan $\mathrm{pH}$ ikan. Pengamatansecara langsung dilakukan denganmengikuti proses penangkapan, pembongkaran di dermaga, dan pelelangan di TPI. Pengujian sifat organoleptik dan $\mathrm{pH}$ ikan dilakukan pada 3 titik yaitu : (1)Saat di kapal setelah ikan mati; (2)Saat di TPI sebelum dilelang; dan (3) Saat di TPI setelah dilelang. Pengamatan dilakukan terhadap 5 jenis ikan yang dominan tertangkap pada setiap trip dengan masing-masing 3 kali ulangan pada setiap titik pengamatan.

Pengujian sifat organoleptik ikan dilakukan dengan mengamati kondisi mata, insang, lendir permukaan badan, bau,dantekstur dengan rentang nilai 1-9 yang mengacu pada score sheet pengujian (SNI 01-2346-2006). Pengukuran $\mathrm{pH}$ daging ikan dilakukan dengan menggunakan $\mathrm{pH}$ meter. Pengamatan lain dilakukan terhadap fasilitas penanganan di atas kapal, fasilitas penanganan di TPI, cara penanganan di atas kapal, cara penanganan di TPI, dan waktu transit dengan nilai konversi dari data kualitatif menjadi data kuantitatif. Gambar 2 memperlihatkan alur penelitian. 


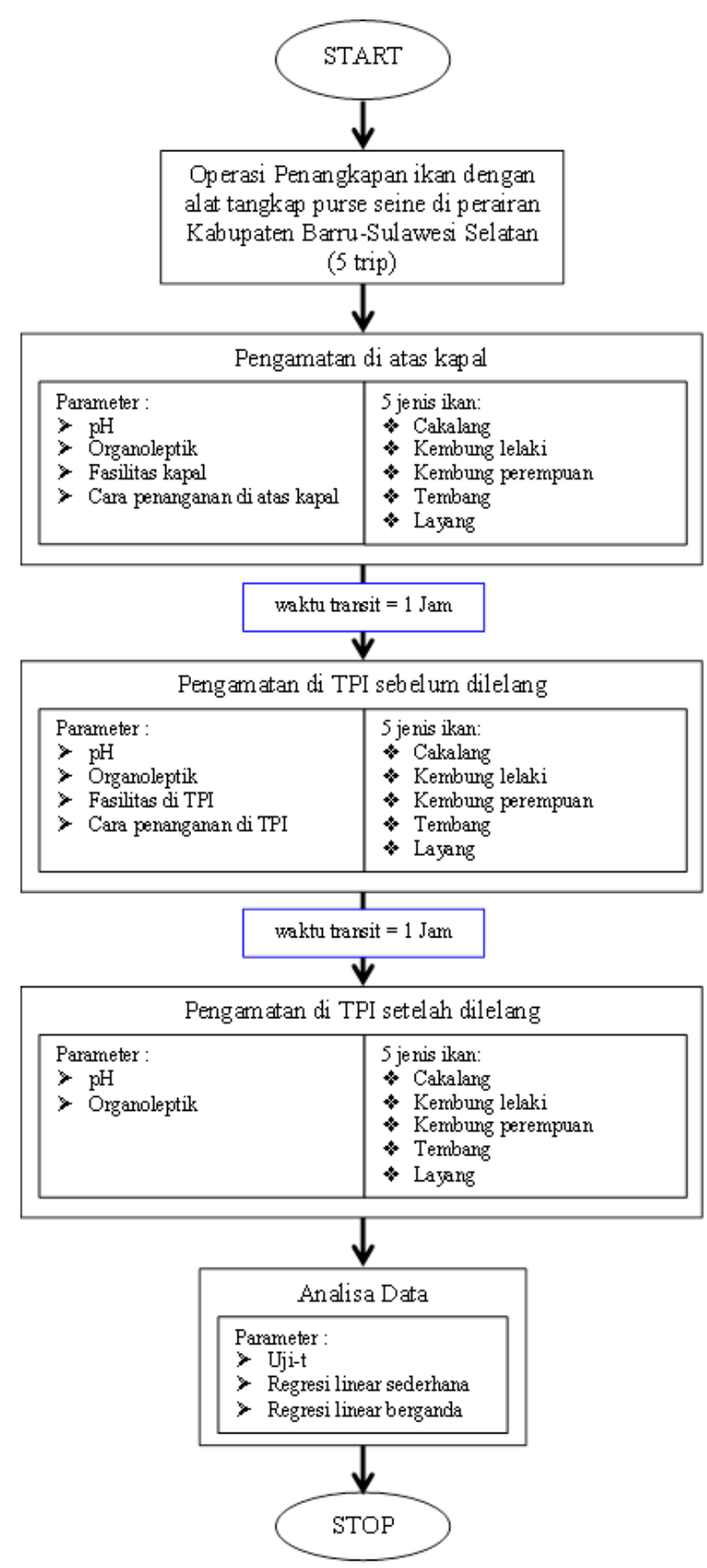

Gambar 2. Alur penelitian

\section{HASIL DAN PEMBAHASAN}

Alat tangkap purse seine banyak dioperasikan pada lokasi tersebut karena perairan memiliki kedalaman yang cukup serta merupakan jalur migrasi ikan. Jenis ikan yang tertangkap selama penelitian di Kabupaten Barru merupakan kelompok ikan permukaan (pelagis).Hal ini sesuai dengan pendapat Widodo dkk. (2010), bahwa penangkapan dengan purse seine merupakan salah satu metode yang agresif dan ditujukan untuk gerombolan ikan pelagis. Hasil tangkapan purse seine di perairan Barru adalah ikan-ikan pelagis jenis layang, tongkol, selar, dan tembang. Tabel 1. menunjukkan jenis ikan hasil tangkapan.

Tabel 1. Jenis ikan hasil tangkapan

\begin{tabular}{cl}
\hline No. & \multicolumn{1}{c}{ Ikan hasil tangkapan } \\
\hline 1. & Cakalang (Katsuwonus pelamis) \\
2. & $\begin{array}{l}\text { Kembung Lelaki (Rastrelliger } \\
\text { kanagurta) }\end{array}$ \\
3. & $\begin{array}{l}\text { Kembung perempuan(Rastrelliger } \\
\text { brachysoma) }\end{array}$ \\
4. & Tembang (Sardinella) \\
5. & Layang (Decapterus ruselli) \\
6. & Julung-julung (Hemirhamphus far) \\
7. & Merah mata besar (Priacanthus \\
& tayenus) \\
8. & Terbang (Cypsilurus poecilopterus) \\
9. & Biji nangka (Upeneus mollucensis) \\
10. & Teri (Stolephorus indicus.)
\end{tabular}

\section{Nilai Organoleptik Hasil Tangkapan}

Pengujian mutu organoleptik bersifat subyektif yaitu penilaian berdasarkan pengamatan secara langsung yang mengacu pada score sheet dengan rentang nilai tertentu. Penilaian tersebut merupakan cara yang paling banyak dilakukan dalam menentukan tanda-tanda kesegaran ikan karena lebih mudah dan cepat, tidak memerlukan banyak peralatan dan laboratorium. Nilai terhadap parameter atau indikator penilaianmakin tinggi menunjukkan makin bagus kondisi 
kesegaran ikan (Hadiwiyoto, 1993).Nilai organoleptik yang dimaksud dalam pembahasan ini adalah rerata dari nilai kondisi mata, insang, lendir permukaan badan, bau, dan tekstur ikan dengan rentang $1 \mathrm{~s} / \mathrm{d}$ 9. Tabel 2. meunjukkan nilai rata-rata organoleptik ikan yang tertangkap dan telah dilelang di Tempat Pelelangan Ikan (TPI).

Nilai organoleptik kelima jenis ikan yang dominan tertangkap yaitu berkisar antara 7,20 - 7,65. Nilai tersebut menunjukkan bahwa ikan yang meninggalkan TPI pada lokasi penelitian tergolong ikan berkualitas baik meskipun telah mengalami sedikit penurunan mutu.Penurunan mutu tersebut terlihat dari penurunan nilai organoleptik dari nilai awal 9 sesaat setelah ikan mati diatas kapal.

Tabel 2. Nilai rata-rata organoleptik ikan yang tertangkap setelah dilelang ( $\alpha$ $=0,05$ )

\begin{tabular}{lcc}
\hline \multicolumn{1}{c}{ Jenis ikan } & $\begin{array}{c}\text { Nilai } \\
\text { organoleptik }\end{array}$ & Signifikansi \\
\hline Cakalang & 7,60 & 0.368 \\
Kembung & 7,65 & 0.641 \\
$\begin{array}{l}\text { Lelaki } \\
\text { Kembung }\end{array}$ & 7,32 & 0.176 \\
$\begin{array}{l}\text { Perempuan } \\
\text { Tembang }\end{array}$ & 7,45 & 0.670 \\
Layang & 7,20 & 0.272 \\
\hline
\end{tabular}

Hal ini sesuai dengan SNI (2006), bahwa ikan hasil tangkapan dengan nilai organoleptik berkisar antara 7 sampai 9 dikategorikan sebagai ikan kualitas baik dan layak dikonsumsi.Hasil uji t (t-test) dengan tingkat kepercayaan $95 \% \quad(\alpha=0.05)$ diketahui bahwa tidak ada perbedaan signifikan ( $p>0.05)$ antara nilai organoleptik kelima jenis ikan, Hal tersebut menunjukkan bahwa tingkat kesegaran atau kualitas ikan yang baik pada hasil tangkapan dengan purse seine. Tabel 3. menunjukkan nilai fasilitas penanganan di atas kapal dan TPI. Hal ini menunjukkan bahwa nelayan purse seine dan pihak yang berwenang di TPI pada Kabupaten Barru menggunakan fasilitas yang yaitu sebagian besar menggunakan peti berinsulasi sebagai wadah penyimpanan/ penampungan ikan.Hadiwiyoto (1993), menyatakan bahwa untuk mempertahankan kesegaran ikan pasca tangkap harus didukung oleh ketersediaan fasilitas penanganan di atas kapal dan di TPI seperti es, keranjang / basket, styrofoam/peti berinsulasi, dan palka. Namun demikian wadah yang tersedia masih minim karena kondisinya kotor dan cenderung tidak terawat.

Tabel 3. Nilai fasilitas penanganan ikan.

\begin{tabular}{|c|c|c|}
\hline Fasilitas & Nilai & Signifikansi \\
\hline \multirow{5}{*}{ Di atas kapal } & 3 & \multirow{5}{*}{0.667} \\
\hline & 3 & \\
\hline & 3 & \\
\hline & 3 & \\
\hline & 2 & \\
\hline \multirow{5}{*}{ Di TPI } & 3 & \multirow{5}{*}{1.000} \\
\hline & 3 & \\
\hline & 3 & \\
\hline & 3 & \\
\hline & 3 & \\
\hline
\end{tabular}


Nilai cara penanganan ikan di atas kapal dan TPI, ditunjukkan Tabel 4. Penanganan yang dilakukan oleh nelayan purse seine menggunakan es kasar sebagai media pendingin namun porsi es masih kurang dan cara pengesan yang tidak benar. Cara penanganan ikan di TPI menunjukkan nilai yang sama atau tidak berbeda nyata $(p>0,05)$ yaitu menggunakan es kasar dengan cara pengesan yang tidak benar. Cara penanganan hasil tangkapan yang baik adalah menggunakan es curah sebagai media pendingin dengan cara dan porsi yang sesuai, menyimpan di dalam palkah atau peti berinsulasi, merawat ikan selama penyimpanan sampai dengan saat pembongkaran di TPI.

Tabel 4. Nilai carahasil tangkapan

\begin{tabular}{ccc}
\hline $\begin{array}{c}\text { Cara } \\
\text { penanganan }\end{array}$ & Nilai & Signikansi \\
\hline \multirow{3}{*}{$\begin{array}{c}2 \\
\text { Di atas kapal }\end{array}$} & 0.016 \\
& $\frac{2}{2}$ & \\
\hline & $\frac{2}{2}$ & \\
& $\frac{2}{2}$ & \\
Di TPI & $\frac{2}{2}$ & \\
& $\frac{2}{2}$ & \\
\hline
\end{tabular}

Tabel 5. menunjukkan waktu transit ikan hasil tangkapan. Waktu transit merupakan waktu yang diperlukan untuk memindahkan ikan dari kapal hingga selesai dilelang di TPI. Waktu transit ikan hasil tangkapan berkisar $5-7$ jam. Waktu transit secara statistik uji-t menunjukkan bahwa tidak berbeda nyata $(p>0,05)$. Dengan demikian kelima variabel yaitu fasilitas penanganan di atas kapal dan TPI; cara penanganan ; serta waktu transit ikan hasil tangkapan dengan purse seine di Kabupaten Barru secara umum sesuai ( $p>0,05)$, kecuali cara penanganan di atas kapal berbeda $(\mathrm{p}<0,05)$.

Tabel 5. Waktu transit ikan hasil tangkapan

\begin{tabular}{|c|c|c|}
\hline \multirow{6}{*}{ Waktu transit } & $\begin{array}{c}\text { Durasi } \\
\text { (jam) }\end{array}$ & Signifikansi \\
\hline & 7.07 & \multirow{5}{*}{0.333} \\
\hline & 3.78 & \\
\hline & 6.38 & \\
\hline & 5.65 & \\
\hline & 5.08 & \\
\hline
\end{tabular}

\section{Pengaruh Waktu Transit dengan Nilai Organoleptic}

Salah satu faktor yang mempengaruhi kecepatan penurunan mutu hasil tangkapan yang akan dipasarkan adalah waktu transit yaitu waktu yang diperlukan untuk penanganan dan perpindahan ikan sejak dari atas kapal hingga selesai dilelang. Semakin lama waktu transit semakin cepat pula ikan mengalami penurunan mutu. Waktu transit yang lama tanpa penerapan suhu rendah memberikan kesempatan berlangsungnya aktivitas enzimatis, biokimiawi dan bakteriologis yang lebih cepat. Produk yang terbentuk dari aktivitas tersebut dapat diketahui melalui berbagai metode salah satunya adalah pengamatan secara organoleptik (Zakaria, 2008). Hal ini juga diungkapkan oleh Wulandari (2007) bahwa 
adanya perantara agen dalam kegiatan distribusi akan berlangsung baik jika pendistribusian cepat dalam hal ini waktu yang digunakan singkat.Gambar 1 memperlihatkan grafik pengaruh waktu transit dengan nilai organoleptik hasil tangkapan tiap jenis ikan.

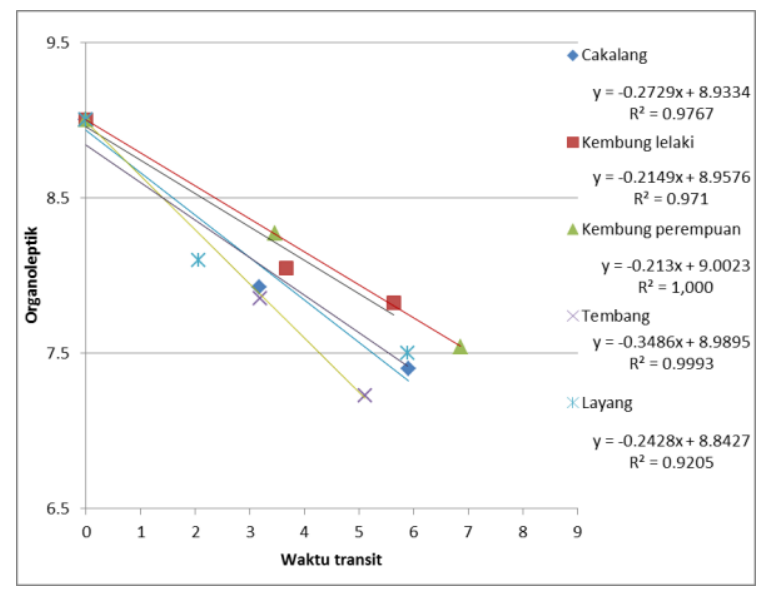

Gambar 3. Pengaruh waktu transit dengan nilai organoleptik hasil tangkapan tiap jenis ikan

Berdasarkan analisa regresi linear sederhana diketahui bahwa waktu transit dan nilai organoleptik lima jenis ikan yang ditangkap memiliki hubungan sangat kuat yang ditunjukkan oleh nilai koefisien korelasi $\quad(R>0,90)$. Nilai organoleptik menurun seiring dengan bertambahnya waktu transit, artinya semakin lama waktu transit semakin besar pula penurunan mutu organoleptik ikan yang ditandai dengan koefisien regresi (r) negatif. Persamaan regresi yang diwakili oleh ikan cakalang yaitu $\mathrm{Y}=-0,2376 \mathrm{X}+8,8825$.
Persamaan tersebut menggambarkan bahwa jika waktu transit $(\mathrm{X})=0$ maka nilai organoleptik $(Y)=8,8825$. Koefisien regresi (r) sebesar -0,2376 berarti jika waktu transit (X) meningkat satu satuan maka nilai organoleptik (Y) menurun sebesar 0,2376X. Fenomena yang sama juga terjadi pada empat jenis ikan yang lain.Total waktu transit kelima jenis ikan sejak diatas kapal hingga selesai dilelang adalah 4,17 jam.

Hasil uji-t menunjukkan bahwa waktu transit keduanya tidak berbeda nyata ( $p>0,05)$. Hal ini didukung oleh nilai organoleptik kelima jenis ikan yang juga tidak berbeda nyata pada kedua lokasi. Pengaruh waktu transit dengan nilai organoleptik masing-masingjenis ikan diketahui melalui penggabungan data seperti diperlihatkan Gambar 3.

Hasil analisa menunjukkan bahwa waktu transit dengan nilai organoleptik kelima jenis ikan memiliki hubungan yang sangat kuat ditunjukkan dengan koefisien korelasi $(\mathrm{R}$ > 0,90). Koefisien regresi (r) negatif berarti semakin bertambah waktu transit semakin menurun pula nilai organoleptik. Persamaan regresi kelima jenis ikan berturut-turut adalah cakalang $\left(\mathrm{Y}=-0,2729 \mathrm{x}+8,9334 ; \mathrm{R}^{2}\right.$ $=0,9767 ; \mathrm{R}=0,9883)$; kembung lelaki $(\mathrm{Y}=$ $\left.-0,2149 \mathrm{x}+8,9576 ; \mathrm{R}^{2}=0,971 ; \mathrm{R}=0,9854\right) ;$ kembung perempuan $(\mathrm{Y}=-0,213 \mathrm{x}+9,0023$; $\left.\mathrm{R}^{2}=1,000 ; \mathrm{R}=1,000\right) ;$ tembang $(\mathrm{Y}=$ $\left.0,3486 x+8,9895 ; R^{2}=0,9993 ; R=0,9996\right) ;$ dan layang $\left(\mathrm{Y}=-0,2428 \mathrm{x}+8,8427 ; \mathrm{R}^{2}=\right.$ 
0,9205; $\mathrm{R}=0,9594)$. Waktu transit Fasilitas penanganan di atas kapal dan cara mempengaruhi nilai organoleptik penanganan di atas kapal tidak berpengaruh ditunjukkan dengan persamaan regresi $\mathrm{Y}=-$ nyata $(\mathrm{p}>0,05)$ terhadap perubahan nilai $0,2572 \mathrm{x}+8,9756 ; \mathrm{R}^{2}=0,9956 ; \mathrm{R}=0,9975$. organoleptik ikan sedangkan waktu transit Persamaan diperoleh melalui penggabungan berpengaruh nyata $(p<0,05)$. Persamaan data kelima jenis ikan. Gambar regresi yang diperoleh adalah $\mathrm{Y}=7,340$ 4.memperlihatkan grafik pengaruh waktu $0,464{ }_{1} X_{1}+0,621_{3} X_{3}+0,152{ }_{5} X_{5}$ dimana $X_{1}$ transit terhadap nilai organoleptik.

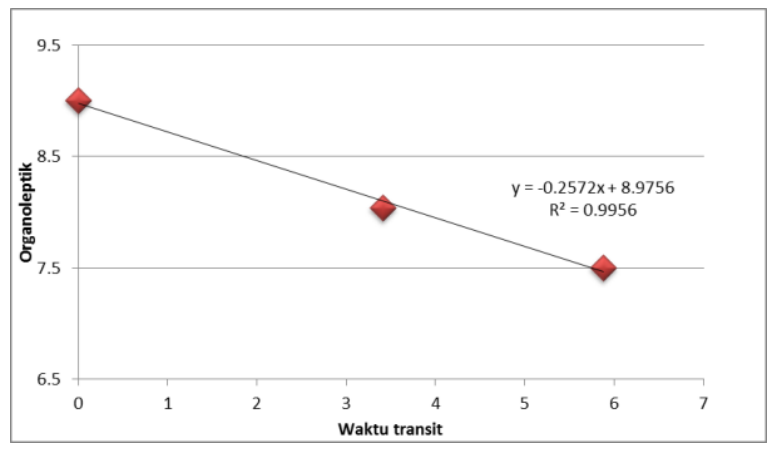

$=$ Fasilitas penanganan di atas kapal, $\mathrm{X}_{3}=$ cara penanganan di atas kapal, $\mathrm{X}_{5}=$ waktu transit, dengan nilai $\mathrm{R}^{2}=0,474$. Berdasarkan analisa tersebut menggambarkan bahwa ketiga variabel memberikan pengaruh sebesar $47 \%$ sisanya $53 \%$ dipengaruhi oleh variabel lain yang tidak termasuk dalam persamaan.

Gambar 4. Pengaruh waktu transit dengan nilai organoleptik hasil tangkapan

\section{Pengaruh Waktu Transit dengan pH}

Nilai $\mathrm{pH}$ yang didapat berkisar antara

Hasil analisis tersebut memberikan persamaan $\mathrm{Y}=5,381+0,160{ }_{1} \mathrm{X}_{1}+0,285_{5} \mathrm{X}_{5}$, dimana $X_{1}=$ fasilitas penanganan di atas kapal dan $\mathrm{X}_{5}=$ waktu transit dengan nilai $\mathrm{R}^{2}$ $=0,371$. Hal ini berarti bahwa $37,1 \%$ sifat organoleptik dipengaruhi oleh fasilitas penanganan di atas kapal dan waktu transit sedangkan sisanya $67 \%$ dipengaruhi oleh parameter lain. Hasil analisis regresi berganda menunjukkan bahwa terdapat tiga variabel yang muncul dalam persamaan, yaitu fasilitas penanganan di atas kapal, cara penanganan di atas kapal, dan waktu transit, sedangkan dua variabel yang lain tidak dimunculkan karena terjadi kolinearitas. 5,65 sampai 5,85. Nilai $\mathrm{pH}$ tersebut telah mengalami penurunan dari nilai awal 6,37 setelah ikan mati. Hal ini sesuai dengan pendapat Eskin (1990), bahwa setelah ikan mati, sirkulasi darah terhenti yang mengakibatkan runtutan perubahan yang terjadi dalam otot/jaringan ikan. Berawal dari terhentinya sirkulasi darah yang mengakibatkan terhentinya suplai $\mathrm{O}_{2}$ sehingga mempengaruhi metabolisme dalam tubuh. Pernapasan terhenti dan mengakibatkan terjadinya proses glikolisis yang mengubah glikogen menjadi asam laktat yang akan menurunkan pH tubuh ikan. Wangsadinata (2008), menyatakan bahwa $\mathrm{pH}$ ikan saat proses produksi dan saat 
pelelangan mengalami penurunan karena adanya proses perubahan glikogen menjadi asam laktat. Tabel 6. Menunjukkan pH ikan hasil tangkapan.

Tabel 6. pH ikan hasil tangkapan

\begin{tabular}{lcc}
\hline \multicolumn{1}{c}{ Jenis ikan } & Nilai pH & Signifikansi \\
\hline Cakalang & 5.70 & 0.682 \\
Kembung laki-laki & 5.85 & 0.596 \\
Kembung perempuan & 5.80 & 0.695 \\
Tembang & 5.65 & 0.451 \\
Layang & 5.66 & 0.362 \\
\hline
\end{tabular}

Berdasarkan uji-t pada tingkat kepercayaan $95 \%(\alpha=0,05)$ didapatkan hasil bahwa tidak ada perbedaan $(p>0,05)$ nilai pH pada kelima jenis ikan yang dominan tertangkap. Hal ini berarti bahwa tidak ada perbedaan tingkat kesegaran atau kualitas ikan. Nilai pH tersebut menunjukkan bahwa ikan setelah dilelang masih dikategorikan segar atau baik karena nilai $\mathrm{pH}<$ 7(Hadiwiyoto, 1993).

Waktu transit dan $\mathrm{pH}$ memiliki korelasi yang sangat kuat. Hal ini terlihat dari koefisien regresi $(\mathrm{R}>0,90)$. Waktu transit mempengaruhi $\mathrm{pH}$, semakin lama waktu transit maka semakin besar pula penurunan $\mathrm{pH}$, begitupun sebaliknya. Hal inidisebabkan oleh proses glikolisis sudah mulai berlangsung yang mengubah glikogen menjadi asam laktat sehingga akan menurunkan pH (Hadiwiyoto, 1993). Ratarata total waktu transit kelima jenis ikan sejak di atas kapal sampai selesai proses pelelangan yaitu 4.17 sampai 5,59 jam. Nilai $\mathrm{pH}$ ikan setelah dilelang kurang dari 7 yaitu berkisar antara 5,38 sampai 5,92 artinya kualitas ikan dikategorikan segar atau baik dan layak untuk dikonsumsi. Hasil persamaan regresi dapat dilihat nilai cakalang $\left(\mathrm{Y}=-0,1016 \mathrm{x}+6,248 ; \mathrm{R}^{2}=\right.$ 0,9149); kembung lelaki ( $\mathrm{Y}=-0,0981 \mathrm{x}+$ 6,3794; $\left.\mathrm{R}^{2}=0,896\right)$; kembung perempuan $\left(\mathrm{Y}=-0,105 \mathrm{x}+6,391 ; \mathrm{R}^{2}=0,9996\right)$; tembang $\left(\mathrm{Y}=-0,1278 \mathrm{x}+6,2888 ; \mathrm{R}^{2}=0,9645\right)$; layang $\left(\mathrm{Y}=-0,0686 \mathrm{x}+6,0928 ; \mathrm{R}^{2}=0,9927\right)$. Gambar 5. memperlihatkan grafik pengaruh waktu transit dengan $\mathrm{pH}$ ikan hasil tangkapan tiap jenis ikan.

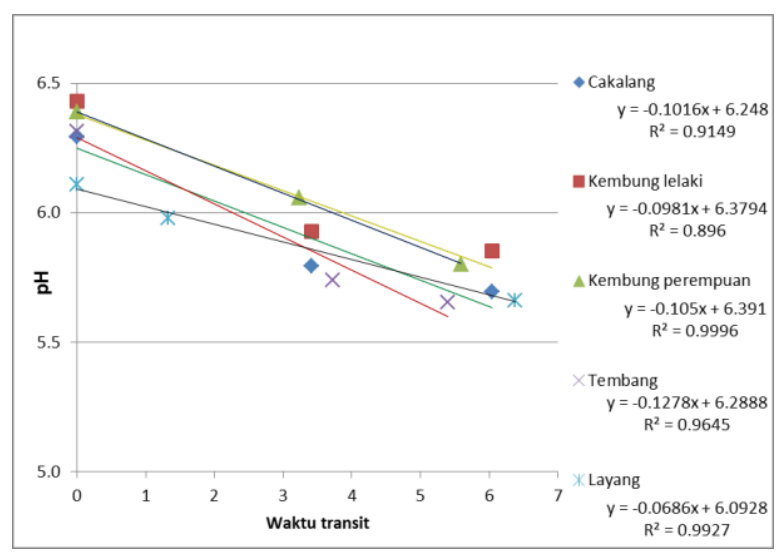

Gambar 5. Pengaruh waktu transit dengan $\mathrm{pH}$ ikan hasil tangkapan tiap jenis ikan

Pengaruh waktu transit terhadap $\mathrm{pH}$ setiap jenis ikan dapat diketahui dengan penggabungan semua jenis ikan tertangkap dengan waktu transit. Hasil analisa regresi secara keseluruhan jenis ikan memberikan persamaan pengaruh waktu transit terhadap $\mathrm{pH}$ yaitu $\mathrm{Y}=-0,1026 \mathrm{x}+6,3373$. Artinya 
jika $\mathrm{X}($ waktu transit $)=0$, maka $\mathrm{Y}(\mathrm{pH})=$ 6,3373 . Nilai koefisien regresi (r) sebesar 0,1026, memberi makna bahwa jika waktu transit mengalami kenaikan satu satuan, maka nilai $\mathrm{pH}$ akan menurun sebesar 0,1026x. Gambar 6. memperlihatkan grafik pengaruh waktu transit terhadap $\mathrm{pH}$ ikan hasil tangkapan.

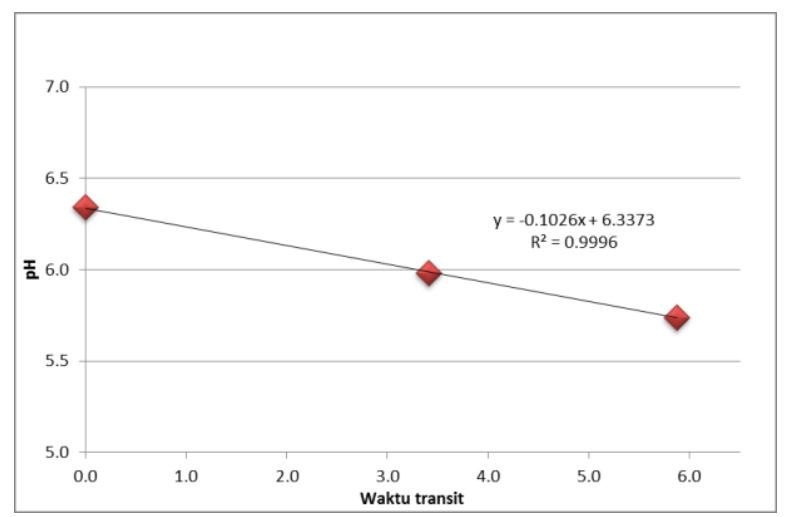

Gambar 6. Pengaruh waktu transit terhadap pH ikan hasil tangkapan.

\section{Pengaruh pH dengan Organoleptik}

Hasil analisa regresi menunjukkan bahwa hubungan nilai $\mathrm{pH}$ kelima jenis ikan dengan sifat organoleptik pada kedua lokasi penelitian memiliki korelasi yang sangat kuat ( $\mathrm{R}>$ 0,90). Penurunan nilai $\mathrm{pH}$ dan organoleptik memiliki pola yang serupa, artinya semakin besar penurunan $\mathrm{pH}$ semakin besar pula penurunan nilai organoleptik., tapi ini hanya berlaku pada rentang nilai $\mathrm{pH} 5,5-7,00$. Gambar 7 . berikut memperlihatkan grafik pengaruh $\mathrm{pH}$ dengan organoleptik tiap jenis ikan.

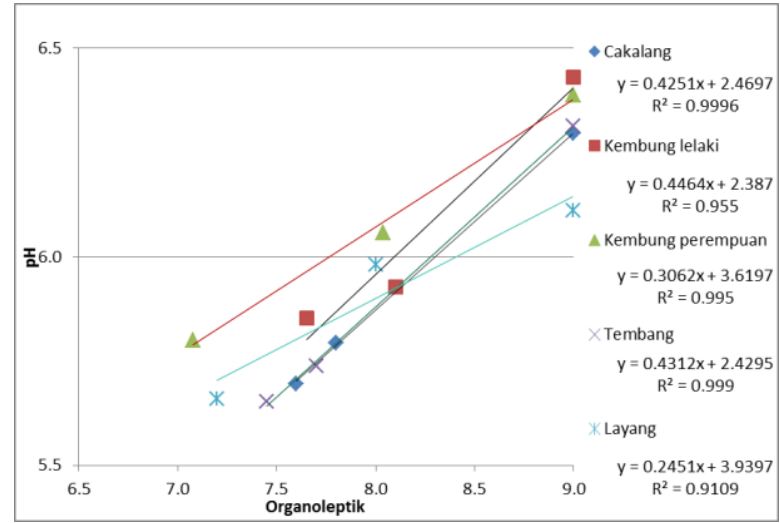

Gambar 7. Pengaruh pH dengan organoleptik tiap jenis ikan

Hasil analisa regresi secara keseluruhan tanpa melihat per jenis ikan menghasilkan persamaan $\mathrm{Y}=0,3978 \mathrm{x}+2,7662$, artinya jika $\mathrm{X}(\mathrm{pH})=0$, maka $\mathrm{Y}$ (organoleptik) = 2,7662 dengan koefisien regresi (r) 0,3978, maka jika nilai organoleptik mengalami kenaikan satu satuan, maka nilai $\mathrm{pH}$ akan mengalami peningkatan sebesar 0,3978x. Gambar 8. berikut memperlihatkan grafik pengaruh $\mathrm{pH}$ dengan organoleptik.

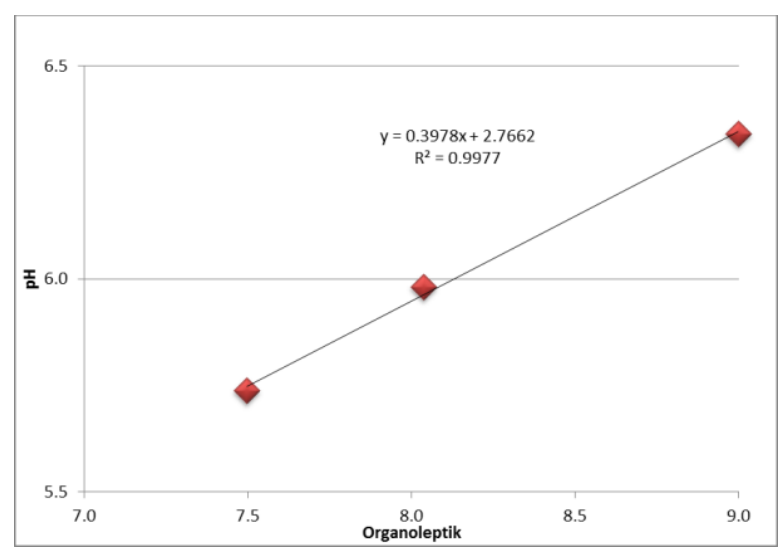

Gambar 8. Pengaruh pH dengan organoleptik

Metusalach dkk. (2012), menyatakan bahwa $\mathrm{pH}$ daging ikan akan mengalami penurunan hanya sampai batas tertentu 
(sekitar $\mathrm{pH}$ 5,5). Hal ini terkait dengan ketersediaan cadangan glikogen di dalam daging. Jika cadangan glikogen telah habis terurai maka $\mathrm{pH}$ daging akan berhenti mengalami penurunan. Penguraian protein dan komponen selain protein yang mengandung nitrogen selama proses kemunduran mutu akan meningkatkan $\mathrm{pH}$ daging ikan, dan semakin tinggi tingkat pembusukan maka akan semakin tinggi pula pH. Ikan busuk memiliki pH sekitar 10-11. Nilai organoleptik akan terus mengalami penurunan sampai nilai terendah. Ikan busuk (berbau busuk) memiliki nilai organoleptik < 2.Hadiwiyoto (1993 mengemukakan bahwa setelah ikan mati $\mathrm{pH}$ daging yang ditangani dengan baik akan menurun secara bertahap dari 7,0 hingga 5,5 akibat akumulasi asam laktat. Penurunan $\mathrm{pH}$ tersebut berlangsung selama $6-8$ jam. Nilai pH ikan tidak pernah mencapai nilai dibawah 5,3 karena pada kondisi tersebut enzim-enzim yang yang terlibat dalam glikolisis anaerob tidak aktif bekerja. pH ikan secara umum menurun dari 6,35 - 5,75 selama $4-7$ jam.

Kelima jenis ikan tersebut yang paling cepat mengalami penurunan mutu adalah ikan kembung lelaki, kemudian diikuti ikan tembang, kembung perempuan, cakalang, dan layang. Hal ini disebabkan oleh cara penanganan di atas kapal yang diterapkan tidak tepat karena ikan yang ditangkap langsung diangkat ke dek kapal dan hasil tangkapan dibiarkan begitu saja sampai mati tanpa perlakuan seperti memisahkan jenis ikan yang sama, menggunakan wadah yang bersih, dan menerapkan prinsip penanganan yaitu ditangani dengan cepat, hati-hati, bersih, dan menjaga rantai dingin.

\section{KESIMPULAN}

1. Tidak terdapat perbedaan antara fasilitas penanganan di atas kapal, fasilitas penanganan di TPI, cara penanganan di TPI, dan waktu transit ( $p>0,05)$.

2. Waktu transit mempengaruhi kualitas organoleptik dan $\mathrm{pH}$ ikan dengan nilai organoleptik dapat diprediksi dengan persamaan regresi $\mathrm{Y}=-0,2572 \mathrm{x}+$ 8,9756; $\quad \mathrm{R}^{2}=0,995 ; \quad \mathrm{R}=0,9975$, sedangkan nilai $\mathrm{pH}$ dapat diprediksi dengan persamaan $Y=-0,1026 x+$ 6,$3373 ; R^{2}=0,9996 ; R=0,9998$.

3. Hubungan nilai $\mathrm{pH}$ dengan organoleptik sangat erat dan dapat diprediksi berdasarkan persamaan $\mathrm{Y}=0,3978 \mathrm{x}+$ 2,$7662 ; R^{2}=0,9977 ; R=0,9988$. Artinya jika $\mathrm{X}$ (organoleptik $)=0$ maka $\mathrm{Y}(\mathrm{pH})=$ 2,7662 .

4. Uji hubungan nilai organoleptik dengan 5 variabel bebas untuk purse seine diperoleh persamaan regresi $\mathrm{Y}=7,293$ $0,146{ }_{1} X_{1}+0,0193 X_{3}+0,126{ }_{5} X_{5} ; R^{2}=$ 0,171 yang berarti ketiga variabel memberikan pengaruh sebesar $17,1 \%$ terhadap organoleptik, sedangkan $82,9 \%$ dipengaruhi variabel lain yang tidak 
termasuk dalam persamaan. Waktu transit merupakan variabel yang berpengaruh signifikan $(p<0,05)$ terhadap perubahan nilai organoleptik ikan, sedangkan fasilitas dan cara penanganan diatas kapal berpengaruh tidak signifikan ( $>0,05)$. Sedangkan Hubungan antara $\mathrm{pH}$ dengan variabel bebas diperoleh persamaan $\mathrm{Y}=5,697-0,076_{1} \mathrm{X}_{1}+$ $0,123_{3} \mathrm{X}_{3}+0,012{ }_{5} \mathrm{X}_{5} ; \mathrm{R}^{2}=0,044$ dimana $\mathrm{X}_{1}=$ fasilitas penanganan di atas kapal, $\mathrm{X}_{3}=$ cara penanganan di atas kapal, $\mathrm{X}_{5}=$ waktu transit. Artinya tiga variabel memberikan pengaruh sebesar 4,4\% terhadap $\mathrm{pH}, \quad$ sedangkan $\quad 95,6 \%$ dipengaruhi variabel lain.

\section{DAFTAR PUSTAKA}

Adawyah , R. 2007. Pengolahan dan Pengawetan Ikan. Bumi Aksara : Jakarta.

Wahyono, A. 2000. Rancang Bangun Purse Seine Tuna untuk Daerah Penangkapan Samudra Hindia di Selatan Jawa. Laporan BPPI Semarang.

Aryadi, O. 2007. Pengendalian Kualitas Ikan pada Distribusi Hasil Tangkapan di PPI Cilauteureun Kecamatan Peuk Kabupaten Garut. IPB. Bogor.

AOAC. 1995. Official Methods of Analysis. Association of Official Analytical Chemists, Washington DC. AOAC Publisher.

Faubianty, V. 2008. Kajian Sanitasi di Tempat Pendaratan dan Pelelangan Ikan di PPI Muara Angke serta
Pengaruhnya terhadap Kualitas Ikan yang di Daratkan. Skripsi. IPB. Bogor.

Hadiwiyoto, S. 1993. Teknologi Pengolahan Hasil Perikanan Jilid I. Liberty. Yogyakarta.

Ilyas, S.1983. Teknologi refrigrasi Hasil Perikanan Jilid II. Teknik Pendinginan Ikan. CV Paripurna. Jakarta.

Metusalach, Kasmiati, Fahrul, dan Jaya, I. 2012. Analisis Hubungan antara Cara Penangkapan dan Cara penanganan dengan kualitas ikan yang dihasilkan. Laporan Hasil Penelitian LP2M. Unhas.

Nurimala M, Nurjanah, dan Harja, R. 2009. Kemunduran Mutu Ikan Lele Dumbo (Clarias gariepinus) pada Penyimpanan Suhu Chilling dengan Perlakuan Cara Mati. Jurnal Pengolahan Hasil Perikanan Indonesia Vol XII Nomor 1 Tahun 2009.

Pane, A. B, 2008. Basket Hasil Tangkapan dan Keterkaitannya dengan Mutu Hasil Tangkapan dan Sanitasi di TPI PPN Pelabuhan Ratu. Skripsi. IPB. Bogor.

Priyatno, D. 2011. SPSS Analisis Statistik Data. Media Com. Yogyakarta.

SNI. 2006. Ikan Segar. Standar Nasional Indonesia, SNI 01-2346-2006. Badan Standarisasi Nasional. Jakarta. Indonesia

Sardjono, I. 1979. Buku Pedoman Pengenalan Sumber Perikanan Laut Bagian I. Departemen Pertanian. Jakarta.

Sudirman dan Mallawa, A. 2004. Teknik Penangkapan Ikan. Rineka Cipta. Jakarta.

Suherman, M. 1999. Palka Berinsulasi untuk penanganan Ikan Segar pada Perahu Motor Nelayan Kepulauan Seribu, DKI Jakarta. Skripsi. IPB. Bogor. 
Taher, N. 2010. Penilaian Mutu Organoleptik Ikan Mujair (Tilapia Mossambica) Segar Dingindengan ukuran yang berbeda selama Penyimpanan Dingin. Jurnal Perikanan Kelautan Volume VI Nomor 1.

Wangsadinata, V. 2008. Sistem Pengendalian Mutu Ikan Swanggi (Priacanthus macracanthus) (Studi Kasus di CV Bahari Express, Pelabuhan Ratu, Sukabumi). Skripsi. IPB.Bogor

Widodo, Mandailing, M. dan Herwandi, A. Kelayakan Pengembangan Usaha Perikanan Mini Purse Seine di Kabupaten Bulukumba Sulawesi Selatan. BBPPI. Semarang.

Wulandary. 2007. Tingkat Kebutuhan Es untuk Keperluan Penangkapan Ikan di Pelabuhan Perikanan Samudra Nizam Zachman Jakarta. Skripsi. IPB. Bogor.

Zakaria, R. 2008. Kemunduran Mutu Ikan Gurami (Osphronemus gouramy) Pasca Panen pada Penyimpanan Suhu Chilling. Skripsi. IPB. Bogor. 